\title{
Field Evaluation of a Competitive Lateral-Flow Assay for Detection of Alternaria brassicae in Vegetable Brassica Crops
}

Alison J. Wakeham and Gary Keane, Institute of Science and the Environment, University of Worcester, Henwick Grove, Worcester, WR2 6AJ, UK and Roy Kennedy, Warwickshire College Group, Pershore College, Avonbank, Pershore, Worcestershire, WR10 3JP

\begin{abstract}
Wakeham, A. J., Keane, G., and Kennedy, R. 2016. Field evaluation of a competitive lateral-flow assay for detection of Alternaria brassicae in vegetable brassica crops. Plant Dis. 100:1831-1839.

On-site detection of inoculum of polycyclic plant pathogens could potentially contribute to management of disease outbreaks. A 6-min, in-field competitive immunochromatographic lateral flow device (CLFD) assay was developed for detection of Alternaria brassicae (the cause of dark leaf spot in brassica crops) in air sampled above the crop canopy. Visual recording of the test result by eye provides a detection threshold of approximately 50 dark leaf spot conidia. Assessment using a portable reader improved test sensitivity. In combination with a weather-driven infection model, CLFD

assays were evaluated as part of an in-field risk assessment to identify periods when brassica crops were at risk from $A$. brassicae infection. The weather-driven model overpredicted A. brassicae infection. An automated 7-day multivial cyclone air sampler combined with a daily in-field CLFD assay detected $A$. brassicae conidia air samples from above the crops. Integration of information from an in-field detection system (CLFD) with weather-driven mathematical models predicting pathogen infection have the potential for use within disease management systems.
\end{abstract}

Fungal pathogens occurring on vegetable brassica crops can be difficult to control. The use of mathematical models to summarize the effect of environment on key life-cycle stages of target pathogens has traditionally been used to determine the risk of pathogen infection in crops (Magarey et al. 2005). However, these systems do not provide information on the presence or absence of pathogenic inoculum. Approaches based on the direct measurement of fungal spores in the air have been reported previously (Carisse et al. 2005; Calderon et al. 2002; Kennedy et al. 2000; Rogers et al. 2009; Wakeham and Kennedy 2010). These tests are a useful tool in crop protection if carried out rapidly and accurately. At present, commercial systems for estimating inoculum are laboratory based, often laborious, and require specialist knowledge (Kennedy and Wakeham 2015). As a result, disease symptoms can be visible before laboratory analysis is complete.

Concerns over the use of pesticides and rising production costs provide a platform for the development of inexpensive, rapid, and accurate diagnostic tools to improve management of crop diseases. Assays such as the immunochromatographic test strip (lateral-flow assay) have been used worldwide for home-care diagnostic use since the 1980s (Yager et al. 2008), with current applications in human and veterinary medicine, agriculture, and environmental and forensic sciences (Wong and Tse 2009). Immunochromatographic tests provide a homogenous format (a system which is able to measure bound label without the need to separate bound and free label) with speed, simplicity of use, specificity, and sensitivity, and at low cost. Bangs Laboratories report a production cost of $\$ 0.35$ per test and an average shelf life of 12 to 24 months (www.bangslabs.com; Technote 303). In agriculture, where profit margins are often low, these types of tests have been used by growers to inform disease management decisions. Tests were originally developed in a flow-through format (Miller et al. 1989). However, a range of immunochromatographic test strips are commercially available for the detection of viral, bacterial, and fungal plant pathogens (Danks and Barker 2000). These types of tests have been developed to diagnose the presence or absence of individual pathogens on plants expressing disease symptoms.

Corresponding author: A. J. Wakeham; E-mail: a.wakeham@worc.ac.uk

Accepted for publication 2 May 2016.

http://dx.doi.org/10.1094/PDIS-10-15-1211-RE

(C) 2016 The American Phytopathological Society
There is the potential to apply this technology as an early warning system for the occurrence of inoculum in air samples. This development would require a system to collect and concentrate inoculum into a suitable sample vessel for further testing. Immunoassays have been developed to quantify airborne inoculum captured by passive deposition onto plant surfaces (Jamaux and Spire 1994) or impaction using rotor rods (Schmechel et al. 1996). Alternatively, a microtiter immunospore air sampler (MTIST; Burkard Manufacturing Ltd., Rickmansworth, Hertfordshire, UK) provides collection of air samples by impaction across 32 microtiter wells (Kennedy et al. 2000). Quantification of trapped particulates can then be subjected to enzyme-linked immunosorbent assay (ELISA) and, with suitable antibodies, multiplex assays can be devised (Wakeham et al. 2004). Most of these tests require laboratory processing facilities. A multivial cyclone air sampler (Burkard Manufacturing Ltd.) which collects air samples into successive collection vessels ( 8 by $1.5 \mathrm{ml}$ ) at predetermined time periods has been considered for use in polymerase chain reaction (PCR)-based methods (West and Kimber 2015; West et al. 2008). In contrast, harnessing this sampling technology with immunochromatographic test strips provides an opportunity to measure target inoculum in situ at low cost by the end user (e.g., a grower or consultant).

The combined use of these two technologies (air sampling and immunological processing) could prove a powerful tool across a range of disciplines. The predictive power of this approach could be improved further if used in conjunction with meteorological models (Jones and Harrison 2004; Zink et al. 2012). For example, in horticulture, reduced application of fungicides has been evaluated using a weather-driven forecast model to predict risk of Albugo candida sporulation and infection periods (Minchinton et al. 2013). Combining this approach with concentration of inoculum in an air sample could further improve the predictive outcome of the test and subsequent control of the disease.

This study reports on the development and evaluation of an immunochromatographic test device (competitive immunochromatographic lateral flow device [CLFD]) for risk assessment of the fungal plant pathogen Alternaria brassicae (dark leaf spot) in air samples. A. brassicae causes dark leaf and pod spot on Brassica spp. and is of worldwide occurrence (Hong and Fitt 1996; HumphersonJones 1992). A nectrotroph on host tissue produces asexual spores (conidia) for wind dispersal (McCartney and Fitt 1998). Infection of crops by A. brassicae can result in severe yield losses (Parada et al. 2008). The relationship between important meteorological parameters 
affecting infection and sporulation of $A$. brassicae has been incorporated into a disease forecast model (Kennedy and Graham 1995). Integration of this information with an in-field detection system (CLFD) for A. brassicae in air is evaluated for improved control of dark leaf spot in Brassica oleracea.

\section{Materials and Methods}

Monoclonal antibody production. Nine $A$. brassicae isolates (Warwick HRI, University of Warwick, UK) (Maude and HumphersonJones 1980) were cultured on V8 juice agar (3 g of technical agar, $0.4 \mathrm{~g}$ of calcium carbonate, and $20 \mathrm{ml}$ of V8 juice [Campbell Soup Company, Camden, $\mathrm{NJ}]$ ) for 1 week in darkness at $25^{\circ} \mathrm{C}$. A $5-\mathrm{cm}$ square of mycelium from each inoculated plate was then removed, homogenized in $5 \mathrm{ml}$ of sterile distilled water (SDW), and transferred in $500-\mu \mathrm{l}$ aliquots to $10 \times 5 \mathrm{ml}$ of sterile clarified V8 juice medium (Johnston and Booth 1983). The V8 mycelial suspensions were mixed and then incubated in darkness at $25^{\circ} \mathrm{C}$. At a magnification of $\times 100$, conidial production was observed 7 days later. Using the method described by Lawrie et al. (2002), conidia of $A$. brassicae were collected from liquid culture and suspended in phosphatebuffered saline (PBS; pH 7.2) at a concentration of $10^{5}$ conidia $\mathrm{ml}^{-1}$. Using a Fast Prep device (Qbiogine FP120; Anachem Ltd., Luton, UK), the conidia were mechanically disrupted according to the manufacturer's guidelines $(3 \times 25 \mathrm{~s}$ at a speed setting of 5.5) and then aliquoted into $50-\mu 1$ lots; this preparation was labeled "antigen-A". The fungal culturing procedure was repeated and A. brassicae conidia were suspended in a $0.1 \%$ glucose SDW solution. Following agitation for $1 \mathrm{~h}$ on a wrist-action shaker, the conidial suspension was sprayed directly onto healthy Brussels sprout plants (B. oleracea var. gemmifera 'Golfer'). Inoculated plants were exposed to a relative humidity of $100 \%$ for $48 \mathrm{~h}$ and thereafter retained in a greenhouse held at $18^{\circ} \mathrm{C}$. Two weeks after inoculation, A. brassicae conidia were observed on lesions. Leaf sections bearing sporulating lesions were detached and agitated in PBS for a period of $30 \mathrm{~min}$. Leaf material was removed by filtering the suspension through a membrane of $97-\mu \mathrm{m}$ pore size. Conidia of $A$. brassicae were recovered on a membrane of $37-\mu \mathrm{m}$ pore size and resuspended in $5 \mathrm{ml}$ of PBS $\left(10^{5}\right.$ conidia $\left.\mathrm{ml}^{-1}\right)$. Following mechanical disruption, as described above, the $A$. brassicae suspension was aliquoted into $50-\mu 1$ lots; this preparation was labeled "antigen-B". Three female Balb $\mathrm{C} / \mathrm{Cj}$ substrain mice were each immunized for induction of antibody-secreting spleen cells (Köhler and Milstein 1976) with $50 \mu l$ of antigen-A mixed with an equal volume of Titermax adjuvant (Sigma-Aldrich T-2684). Three additional mice were injected with

Table 1. Fungal species cultured for immunoassay reactivity studies

\begin{tabular}{|c|c|c|c|}
\hline Species & $\begin{array}{l}\text { Growth } \\
\text { media }^{a}\end{array}$ & $\begin{array}{l}\text { Morphological } \\
\text { classification }\end{array}$ & Host isolated \\
\hline Alternaria brassicae & V8 agar & Ellis 1971 & $\begin{array}{l}\text { Brassica } \\
\text { oleracea }\end{array}$ \\
\hline A. dauci & V8 agar & Ellis 1971 & D. carota \\
\hline A. cheranthi & V8 agar & Ellis 1971 & C. cheiri \\
\hline A. alternata & V8 agar & Ellis 1971 & $F$. vespa \\
\hline $\begin{array}{l}\text { Penicillium } \\
\text { waksmanni }\end{array}$ & PDA & Pitt 1988 & Soil \\
\hline Phoma lingam & PDA & $\begin{array}{l}\text { Punithalingam and } \\
\text { Holliday } 1975\end{array}$ & B. napus \\
\hline $\begin{array}{l}\text { Stemphyllium } \\
\text { lycopersici }\end{array}$ & PDA & Ellis 1971 & S. lycopersicum \\
\hline $\begin{array}{l}\text { Pyrenophora } \\
\text { dictyoides }\end{array}$ & PDA & $\begin{array}{l}\text { Ellis } 1971 \\
\quad \text { (Drechslera state) }\end{array}$ & L. perenne \\
\hline Botrytis squamosa & PDA & Ellis 1971 & A. сера \\
\hline Aschochyta fabae & PDA & $\begin{array}{l}\text { Punithalingam and } \\
\text { Holliday } 1975\end{array}$ & V. faba \\
\hline $\begin{array}{l}\text { Aureobasidium } \\
\text { pululans }\end{array}$ & PDA & Ellis 1971 & Air \\
\hline Fusarium solani & PDA & $\begin{array}{l}\text { Booth } 1971 ; \\
\text { Nelson et al. } 1983\end{array}$ & A. сера \\
\hline
\end{tabular}

${ }^{\text {a }}$ V8 agar $=$ V8 juice agar and PDA = potato dextrose agar.
$50 \mu l$ of antigen-B. The same mice were immunized on two further occasions at 14-day intervals without adjuvant.

Collected tail bleeds (Köhler and Milstein 1975) were titrated against their respective homologous antigen preparation by platetrapped antigen (PTA)-ELISA (Kemeny 1991). For each tail bleed, 10 paired wells of a 96-well Nunc Immunosorbent Polysorp flatbottomed microtiter plate (model number 475094; Life Technologies, Paisley, Scotland) were coated with the homologous antigen type in PBS at $100 \mu l$ well ${ }^{-1}$. Ten paired wells received PBS alone at $100 \mu \mathrm{l} \mathrm{well}{ }^{-1}$ for each tail bleed as a control. After overnight incubation at $18^{\circ} \mathrm{C}$, unbound antigen was removed by inverting the individual microtiter plates and tapping them down onto absorbent toweling. The plates received four 1-min washes of PBS at $200 \mu \mathrm{l}$ well ${ }^{-1}$. Wells were blocked with $200 \mu \mathrm{l}$ of $3 \%$ casein buffer (3\% [wt/vol] casein in PBS) and incubated in a Wellwarm shaker incubator (model number W1031B; Denley Instruments Ltd., Sussex, UK) for $30 \mathrm{~min}$ at $30^{\circ} \mathrm{C}$. Residual blocking buffer was removed and wells were washed four times for 1 min each with PBS plus $0.05 \%$ Tween 20 (PBST) at $200 \mu \mathrm{lwell}^{-1}$. Mice tail bleeds were diluted 1:100 in PBST and doubling dilutions were made to 1:25600. A diluted tail bleed was applied $\left(100 \mu \mathrm{l}\right.$ well $\left.{ }^{-1}\right)$ to homologous antigen-coated paired wells. The remaining homologous antigenpaired well of each 10-paired-well set received PBST alone. This process was repeated but with microtiter wells which had not been coated with A. brassicae antigen. After incubation in a Wellwarm 1 shaker incubator as previously described, unbound material was removed and wells were washed (as previously described) four times for 1 min each with PBST. Aliquots of $100 \mu l$ of antimouse immunoglobulin $\mathrm{G}$ (IgG; whole molecule) biotinylated antibody produced in goat (model number B7264; Sigma-Aldrich Company Ltd., London) diluted 1:500 in PBST were added to each well and incubated for $45 \mathrm{~min}$, as above. After washing as previous, streptavidin peroxidase at $100 \mu \mathrm{l}$ well $^{-1}$ (model number SS512; Sigma-Aldrich Company) diluted 1:10000 in PBST was added to each well and incubated as above for $45 \mathrm{~min}$. The microtiter wells were washed as previously described and each well received $100 \mu \mathrm{l}$ of 3,3',5,5'-tetramethylbenzidence substrate (model number T-3405 and P-4922; Sigma-Aldrich). The reaction was stopped by adding $25 \mu \mathrm{l}$ of $2 \mathrm{M} \mathrm{H}_{2} \mathrm{SO}_{4}$. Absorbance was recorded at $450 \mathrm{~nm}$ in an HT11 (Anthos Labtec Instruments, Salzburg, Austria) ELISA plate reader.

Mice with high titer tail bleeds (end point $>1: 32000$ ) to $A$. brassicae were identified. Following a final prefusion boost, the spleen was removed 4 days later. Spleen cell fusions were carried out according to a modified protocol (Kennett et al. 1978), with cell hybrids fed on days 3, 6, and 10. By PTA-ELISA, the cell culture supernatants were screened 14 days after cell fusion to the homologous antigen preparation, as previously described.

Hybridoma cell lines identified as producing antibodies positive to A. brassicae antigen were screened for reactivity to other fungal species (Table 1) by PTA-ELISA. For this process, fungal plate washings were prepared on Supor 450 membrane filter-covered (model number HPWP09050; MERKMillipore, Darmstadt, Germany) inoculated agar plates (Wakeham et al. 1997). Spore suspensions of each fungal isolate were collected and adjusted to $10^{5}$ spores $\mathrm{ml}^{-1}$ (Skottrup et al. 2007). The collected spores were mechanically disrupted using a Fast Prep device, as described previously. By centrifugation for $5 \mathrm{~min}$ at $13,000 \times g$, the particulate fraction was removed and the soluble spore fraction was retained for PTA-ELISA. Paired wells of a 96-well Nunc Immunosorbent Polysorp flat-bottomed microtiter plate (model number 475094 A; Life Technologies) were coated with each fungal washing at $100 \mu \mathrm{l}$ well $^{-1}$ (Dewey et al. 1989). Unbound antigen was removed after overnight incubation at $18^{\circ} \mathrm{C}$ (Wakeham et al. 1997) and the PTA-ELISA process was carried out as previously described with an $A$. brassicae-positive cell culture supernatant. The process was repeated twice for each of the A. brassicae-positive cell culture supernatants.

The immunoglobulin class produced by each Alternaria sp.-positive cell line was determined using an Isostrip mouse monoclonal isotyping kit (model number 11-493-027 001; Roche Diagnostics, Burgess Hill, West Sussex, UK). One of the cell lines 
(coded EMA 212) was selected and the tissue culture supernatant purified using a High Trap IgM purification HP column according to the manufactures instructions (model number 17-5110-01; GE Healthcare, Little Chalfont, UK). The effects of antigen modification with protease and periodate on antibody binding (EMA 212) was determined by the method of Bossi and Dewey (1992). To determine antigen site expression, A. brassicae conidia (Maude and Humpherson-Jones 1980) were collected using the method described by Lawrie et al. (2002). Conidia were germinated in $0.01 \%$ glucose solution on multiwell glass slides (model number MIC3412; Scientific Laboratory Supplies, Nottingham, UK) and by immunofluorescence probed with antibodies produced by the EMA 212 cell line (Kennedy et al. 1999b).

Competitive immunochromatographic test device. Immunochromatographic test strips consisted of a carrier material containing dry reagents that are activated by applying a liquid sample. Movement of this liquid allows passage across various zones (test framework) where molecules are attached and exert specific interactions with target analytes. Results are generated within 5 to 10 min by the formation of a control and test lines as appropriate to the sample and the test type. The development of a control line provides confirmation that the test is valid. In a competitive format (CLFD), the test line result is counterintuitive (i.e., as the target analyte in a sample increases, test line color intensity decreases). At a high concentration of target analyte, no test line is visible and a positive result is recorded. The test can be made semiquantitative with the use of a reader (Wong and Tse 2009).

The test framework was constructed using a Millipore 135 HiFlow cellulose ester membrane direct cast onto a Mylar backing (model number SHF2400225; Millipore Corp., Bedford, MA) attached at either end to an absorbent pad (model number GBOO4, Schleicher and Schuell, Dassel, Germany) and a sample pad (model number T5NM; Millipore Corp.). A control line of a nonimmune antimouse serum and a test line of $A$. brassicae (antigen-A), each adjusted to $0.5 \mathrm{mg}$ $\mathrm{ml}^{-1}$ in PBS, were independently applied to the cellulose ester membrane surface using a flat-bed air-jet dispenser (BioDot Ltd., The Kingley Centre, Chichester, West Sussex, UK) operating at a line travel speed of $50 \mathrm{~m} \mathrm{~s}^{-1}$. The sprayed membranes were air dried overnight at room temperature $\left(18\right.$ to $\left.20^{\circ} \mathrm{C}\right)$ and cut into 5-mm strips. A $500-\mu 1$ volume of EMA $212\left(1 \mathrm{mg} \mathrm{ml}^{-1}\right)$ was mixed with $375 \mu \mathrm{l}$ of a goat antimouse IgM 40-nm gold conjugate (code BA GAMM 40; British Biocell International, Cardiff, UK) made to $2 \mathrm{ml}$ in PBS and incubated on a roller incubator for $3 \mathrm{~h}$. EMA 212 antibodybound gold particles were then collected by centrifugation $(4,000 \times g)$ and resuspended to a final volume of $1.625 \mathrm{ml}$ in application buffer (20 mM sodium phosphate buffer, $100 \mathrm{mM}$ sodium chloride, $0.25 \%$ trehalose, and $0.1 \%$ sucrose, $\mathrm{pH}$ 7.2). The EMA 212 antibody gold conjugate solution $(60 \mu \mathrm{l})$ was then pipetted onto individual CLFD sample pads and air dried at $37^{\circ} \mathrm{C}$ for $30 \mathrm{~min}$. Each pad was attached to the CLFD test strip. The CLFD strips were mounted within a plastic housing device (model number SH 003; European Veterinary Laboratory, Woerden, The Netherlands).

A. brassicae conidia (Warwick HRI; AA3 and AA4 isolated from Brussels sprouts and AA10-1M isolated from kohlrabi) were produced in planta as described above (antigen-B) and collected in extraction buffer $(0.05 \mathrm{M}$ Tris HCL, $0.15 \mathrm{M} \mathrm{NaCl}, 0.4 \%$ Triton $\mathrm{X} 100,0.2 \%$ Tween $20,0.2 \%$ bovine serum albumen, and $0.12 \%$ Geropan). For each isolate, a doubling dilution series was made to provide $100-\mu 1$ aliquots of $A$. brassicae of $6 \times 10^{4}$ conidia/aliquot. Aliquots of each conidial suspension were applied drop wise to the sample pads of individual CLFD strips. A negative control of three CLFD strips received extraction buffer alone. After an assay time of $6 \mathrm{~min}$, the development of test and control lines was recorded visually by eye and then by optical densitometry using a laboratorybased BioDot Quadscan device (BioDot Ltd.).

The fungal species tested previously by PTA-ELISA were grown in sterile culture as described previously but were collected in CLFD extraction buffer. A culture of Mycosphaerella brassicicola (singlespore isolate $\mathrm{CH} 195001$ ) was maintained on sprout decoction agar with illuminated low-intensity substage fluorescent lighting for production of pseudothecia (Kennedy et al. 1999b). Ascospores were identified on the underside of each petri dish lid $(\times 100$ bright-field microscopy) and removed in CLFD buffer by gentle agitation with a glass spreader (Kennedy et al. 1999b). Similarly, Pyrenopeziza brassicae mating types MAT-1 and MAT-2 (Foster et al. 2002) were cultivated on compost agar for apothecial development and the production of ascospores (Gilles et al. 2001). For each fungal species, spore concentrations were adjusted to $<10^{5}$ $\mathrm{ml}^{-1}$ with CLFD buffer. A $100-\mu l$ aliquot of each fungal sample was applied drop wise to the sample pad of individual Alternaria CLFD strips. After an assay time of $6 \mathrm{~min}$, CLFD data were recorded visually for test line development and using a Quadscan reader.

Preliminary field trial study. For a 3-week period, an overwintered, heavily infected (dark leaf spot, ringspot, and white blister) field plot ( 20 by $10 \mathrm{~m}$ ) of Brussels sprouts (Golfer) was monitored continuously for the presence of A. brassicae spores in the air using a Burkard cyclone sampler (model number MEI0073; Burkard Manufacturing Ltd.) at a site in Warwickshire, UK. (Ordnance Survey National Grid [OS] reference SP278552). After each sampling period ( 1 or 3 days), the $1.5-\mathrm{ml}$ sample collection vessel from the cyclone spore trap was removed and taken to the laboratory, where a $110-\mu l$ volume of extraction buffer was then added. The contents of the collection vessel were gently mixed using a disposable micropipette (model number 50504NU; Alpha Lab Ltd., Eastleigh, UK) and a $100-\mu l$ aliquot was transferred to a sample pad of an Alternaria CLFD with assay time and data collection, as described above. The remaining $10 \mu \mathrm{l}$ of extraction buffer was removed from the sample collection vessel and examined using a microscope for the presence of A. brassicae conidia (expressed per cubic meter of air sampled). The risk of $A$. brassicae infection for each of the field sampling periods was assessed by placing six healthy, greenhouse-grown $B$. oleracea trap plants (Golfer, 10 true leaves) in the field plot adjacent to the spore trap. After each air sampling period, trap plants were removed and placed in an isolated environment of $100 \%$ humidity for $48 \mathrm{~h}$ at $16^{\circ} \mathrm{C}$ to fulfill the environmental requirements for infection by $A$. brassicae (Kennedy et al. 1999a). Additionally, six healthy, greenhouse-grown $B$. oleracea plants (which were not exposed to the field) were included as controls. The plants were then air dried and retained in a glasshouse at a temperature of 12 to $14^{\circ} \mathrm{C}$ for 21 days. Plants were visually examined for the expression of dark leaf spot on leaves. Confirmatory isolations from these lesions were recorded on sprout leaf decoction agar to confirm the presence of A. brassicae (Kennedy et al. 1999b).

Field risk assessment studies. In conjunction with a weatherdriven infection model (Kennedy and Graham 1995; Wakeham and Kennedy 2010) A. brassicae CLFD assays were evaluated in commercial fields of Brussel sprouts (OS reference TF509615; Lincolnshire, UK) and cauliflower (OS reference SD430235; Lancashire, UK). Within the fields, three trial plots ( 15 by $15 \mathrm{~m}$ ) were marked. No fungicide application or treatments were made to the crop in these areas. During a 6-week period, daily air samples were collected using a Burkard multivial cyclone sampler adapted for field use (model numbers ME10029, ME10031, and ME10034; Burkard Manufacturing Ltd.). The samplers were preset for an automatic change of the trapping vessel (1.5-ml microfuge tube) each day at a preset time. The tubes within each sampler (one tube for each day) were replaced weekly. The samplers were operated for $12 \mathrm{~h}$ in each day between 5 A.M. and 5 P.M. to match the diurnal periodicity of $A$. brassicae conidial dispersal (Kennedy et al. 1999a). At collection, a 110- $\mu$ l volume of extraction buffer was added to each of the tubes and the contents were mixed, as previously described. A $100-\mu l$ aliquot was transferred from each tube to a sample pad of an A. brassicae CLFD. After $6 \mathrm{~min}$, data on the CLFD were observed visually and with a field-portable, one-step digital immunochromatographic test strip reader (European Veterinary Laboratory). The remaining 10- $\mu$ l suspension of each sample was examined in the laboratory under brightfield microscopy $(\times 400)$ for the presence of A. brassicae conidia. Throughout the sampling period, Brassica leaf spot infection periods were monitored (Kennedy and Graham 1995; Wakeham and Kennedy 2010). For this purpose, canopy-positioned wetness sensors and 
temperature and humidity environmental conditions were monitored with a SKYE Datahog II weather station (Skye Instruments Ltd., Powys, UK) at intervals of $30 \mathrm{~min}$. Throughout the trial period, visual dark leaf spot disease assessments were taken in the unsprayed plots of each crop. Leaves of 10 plants in each plot were tagged and numbered. Recordings were made weekly and isolations were taken from identified dark leaf spot lesions, as previously described.

\section{Results}

Monoclonal antibody selection. Five hybridoma cell lines were identified by PTA-ELISA as producing antibodies with recognition sites to A. brassicae antigen. Three of the cell lines emanated from mice immunized with antigen preparation-A. Two of these produced antibodies isotyped as IgG1 subclass. The other cell line produced IgM class. The remaining two cell lines were derived from mice immunized with antigen preparation-B and isotyped as producing IgM and IgG2a subclass. Only one of these hybridoma cell lines (coded EMA 212, isotype IgM, and yielded from antigen preparation A) provided an antibody type which could be used to detect conidial preparations of A. brassicae in a CLFD format (data not presented). When this hybridoma cell line was assessed by PTA-ELISA, some reactivity to other Alternaria spp. was observed (Fig. 1). Although, with a 10-fold difference observed between A. brassicae and the other the Alternaria spp. tested, this was at a low level. Of those species tested outside of the genus, little or no reactivity with EMA 212 was observed.

Monoclonal antibody characterization. Effects of heat treatment, chemical and enzymatic effect of periodate oxidation, and protease digestion on antigen binding by the antibody type produced by hybridoma cell line EMA212 are shown in Tables 2 to 4. Antibody binding was not affected by heat treatment of the A. brassicae conidial antigen (Table 2). Both periodate and protease reduced antibody binding at each of the temperatures and time periods tested (Tables 3 and 4). This would suggest that the antibody recognized both carbohydrate and protein moieties of a glycoprotein. Heat treatment of the protein did not diminish the reactivity by the monoclonal antibody; this would suggest linear epitopes in the protein molecule. Differential sensitivity to chemical and enzymatic modification illustrates the need to study a range of incubation periods and temperatures. The antibody produced by the EMA 212 cell line was observed by immunofluorescence to bind to an epitope associated with the germ tube of the conidium which dissipated with mycelial growth (Fig. 2).

Competitive immunochromatographic test (CLFD). Using a monoclonal antiserum (produced by hybridoma cell line EMA 212), an immunochromatographic assay was developed to provide a visual

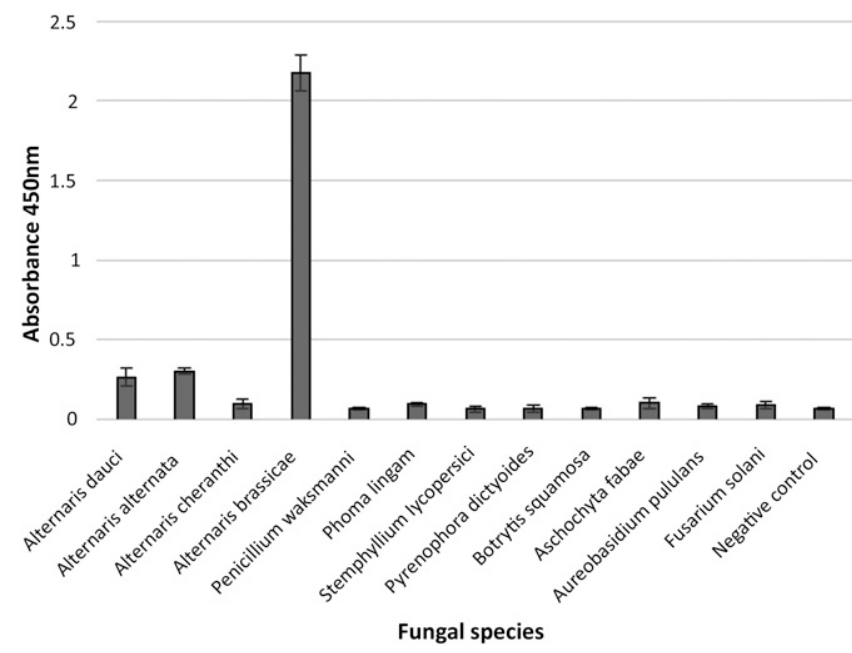

Fig. 1. Reactivity of monoclonal antiserum (hybridoma cell line coded EMA 212) to fungal species Alternaria dauci, A. alternata, A. cheranthi, A. brassicae, Penicillium waksmanni, Phoma lingam, Stemphyllium lycopersici, Pyrenophora dictyoides, Botrytis squamosa, Aschochyta fabae, Aureobasidium pululans, and Fusarium solani by plate-trapped enzyme-linked immunosorbent assay. indicator of A. brassicae presence within an air sample. This is a competitive assay and is counterintuitive (i.e., test line depletion is dependent on increasing A. brassicae concentration; Fig. 3). The test is recorded positive for $A$. brassicae when no test line is observed by visual eye observation. With an assay time of $6 \mathrm{~min}$, approximately 50 A. brassicae spores per $100 \mu \mathrm{l}$ of sample volume are required for depletion of the test line. Test sensitivity was increased approximately fivefold with a laboratory-based optical density (OD) reader (Fig. 4) and provided potential for quantitative measurement of $A$. brassicae in air samples. When other fungal species were tested with the A. brassicae CLFD, a visible test line was evident and OD test line values for each recorded $>5.0$ (i.e., tested negative for $A$. brassicae).

Preliminary field trial study. During the 3 -week monitoring period, an overwintered crop of Brussels sprouts inoculated with $A$. brassicae, five 12-h-day periods of air sampling were identified by the CLFD assay as positive for conidia of $A$. brassicae. For each of these periods, no visible CLFD test line was recorded and the OD test line values recorded by the Quadscan reader gave a value of $<2$ OD. On each of these dates, the total numbers of dark leaf spot lesions on the six trap plants exceeded 13. For all other sampling periods, all trap plants were negative for dark leaf spot lesions (A. brassicae).

Field risk assessment studies. Daily $A$. brassicae infection score ratings over the 6-week observation period resulted in 10 days designated moderate risk (infection score 100 to 150 ) and 15 days designated high risk (infection score $>151$ ). Infection scores $<100$ were interpreted as low risk. With the weather-driven model for each week of the 6-week observation period, at least at least one daily A. brassicae infection risk period was identified (Fig. 5). In contrast, the CLFD assay performed daily on collected air samples detected A. brassicae on only 3 days $(13,14$, and 23 August) by both visual and field-portable strip reader. Microscopic examination of each daily collected field air sample showed a correlation $\left(r^{2}=0.8081\right)$ with the number of $A$. brassicae conidia trapped and the corresponding fieldportable EVL immunochromatographic test strip reading (Fig. 6).

For the three dates where the CLFD test determined A. brassicae to be at an air sample threshold risk in the crop, the environmental model recorded a moderate or high risk of A. brassicae infection. Evaluation of the tagged Brussels sprout plants prior to the start of the experiment (3 August) revealed a level of dark leaf spot incidence already within the crop (10 lesions plant $\left.{ }^{-1}\right)$. Thereafter, two distinct phases of dark leaf spot development occurred on the tagged Brussels sprout plants over the 6-week period (Fig. 7). The second phase of dark leaf spot symptom expression was recorded on the tagged plants after 26 August.

At the second commercial site (cauliflower crop), the weatherdriven model identified 16 days when the crop was at risk of $A$. brassicae infection. However, visual assessment of the CLFD assay indicated that $A$. brassicae inoculum was either absent or at a low level. Using the portable in-field reader, a single CLFD assay showed a digital reading $<2$ (EVL test reading at 1.6 for 9 to 10 September). For this period, A. brassicae conidia were identified by bright-field microscopy within the collected air sample $\left(5\right.$ conidia $/ \mathrm{m}^{3}$ of air sampled). Ten days later, dark leaf spot establishment (at a low level) was observed within nonfungicide-treated areas of the cauliflower crop.

Table 2. Absorbance values from plate-trapped antigen enzyme-linked immunosorbent assay (PTA-ELISA) tests with heat-treated Alternaria brassicae antigens by using monoclonal antibody EMA 212

\begin{tabular}{lccc}
\hline & & \multicolumn{2}{c}{$\begin{array}{r}\text { PTA-ELISA absorbance } \\
(\mathbf{4 5 0} \mathbf{~ n m})^{\mathbf{a}}\end{array}$} \\
\cline { 3 - 4 } Time $(\mathbf{m i n})$ & Temperature $\left({ }^{\circ} \mathbf{C}\right)$ & PTA-ELISA & Reduction $(\%)$ \\
\hline 0 & n/a & $0.936 \pm 0.045$ & $\ldots$ \\
1 & 100 & $0.961 \pm 0.006$ & 0 \\
3 & 100 & $0.986 \pm 0.025$ & 0 \\
5 & 100 & $0.999 \pm 0.044$ & 0 \\
\hline
\end{tabular}

$\overline{{ }^{a}}$ Each value represents the mean of three replicate values \pm standard errors; $\mathrm{n} / \mathrm{a}=$ not available. 


\section{Discussion}

In this study, two preparation types of $A$. brassicae conidia were used for the production of antibody-producing hybridoma cell lines from female Balb C mice. IgM and IgG subclasses were produced by $A$. brassicae-positive cells lines regardless of the growth medium used for conidial antigen (V8 juice agar culture [antigen A] or Brussels sprout plants [antigen B]). When tested by ELISA or lateral flow (LF), none of the A. brassicae-positive cell lines produced antibodies which could be used in a double-antibody sandwich (DAS) (data not supplied). A DAS assay requires target analyte (antigen) to bind simultaneously to both the reporter and an immobilized "capture" antibody. This cannot be accomplished with small analyte molecules that may have a single antigenic determinant. Additionally, steric hindrance may prevent simultaneous binding. When the target analyte consists of a small molecule, CLFD are often preferred because they do not require an analyte to provide the linkage between the capture and reporter antibody (Qian and Bau 2004). Similarly, this is the case with PTA-ELISA and the processes by which each of the cell lines were initially screened for antibodies reactive to $A$. brassicae antigen.

Interestingly, of the $A$. brassicae-positive hybridoma cell lines selected by this method, only one produced an antibody type (antigen type A, IgM-producing cell line) which could be used within a CLFD assay format. Antibody performance in an LF assay can be very different from that in ELISA, where long incubation times and lower surface concentration exist. For LF, an antibody with high affinity is required (O'Farrell 2013). Typically, IgM antibodies are considered to be of lower affinity than that of IgG preparations (Makela et al. 1997). For this reason, it was surprising that the IgG cell lines did not prove suitable for use. However, high affinity may not be the sole driver in this type of assay because affinity needs to be driven by a fast on-rate ( $\mathrm{k}_{\text {on }}$ or association rate constant). Unlike the ELISA, the test line zone of the LF provides limited time for interaction between the antibody and analyte. A time of 1 and $6 \mathrm{~s}$ for binding has been reported. However, a little more contact time exists between antibody and analyte from the conjugate pad, with the "effective" binding reaction starting with resolubilization of the conjugate and ending after the conjugate passes the test line. This time is typically on the order of 10 to $20 \mathrm{~s}$ (Brown 2008). Malmborg et al. (1992) reported by surface plasmon resonance that IgM anti-Tn $\alpha$ antibodies showed one order of magnitude higher association rate constants, as compared with the IgG antibodies. Also, IgM multivalency (10 binding sites,

Table 3. Absorbance values from plate-trapped antigen enzyme-linked immunosorbent assay (PTA-ELISA) tests with periodate-treated Alternaria brassicae antigens by using monoclonal antibody EMA 212

\begin{tabular}{lcccc}
\hline & & \multicolumn{3}{c}{ PTA-ELISA absorbance $(\mathbf{4 5 0} \mathbf{~ n m})^{\mathbf{a}}$} \\
\cline { 3 - 5 } Time (h) & Temperature $\left({ }^{\circ} \mathbf{C}\right)$ & Periodate & Control & $\begin{array}{c}\text { Reduction } \\
(\%)\end{array}$ \\
\hline 5 & 4 & $0.223 \pm 0.012$ & $0.371 \pm 0.005$ & 40 \\
5 & 37 & $0.150 \pm 0.006$ & $0.324 \pm 0.00$ & 54 \\
24 & 4 & $0.133 \pm 0.014$ & $0.409 \pm 0.034$ & 67 \\
24 & 37 & $0.192 \pm 0.038$ & $0.263 \pm 0.028$ & 27 \\
\hline
\end{tabular}

${ }^{a}$ Each value represents the mean of three replicate values \pm standard errors.

Table 4. Absorbance values from plate-trapped antigen enzyme-linked immunosorbent assay (PTA-ELISA) tests with protease-treated Alternaria brassicae antigens by using monoclonal antibody EMA 212

\begin{tabular}{lcccc}
\hline & \multicolumn{3}{c}{ PTA-ELISA absorbance $(\mathbf{4 5 0} \mathbf{~ n m})^{\mathbf{a}}$} \\
\cline { 2 - 5 } Time (h) & Temperature $\left({ }^{\circ} \mathbf{C}\right)$ & Protease & Control & $\begin{array}{c}\text { Reduction } \\
(\boldsymbol{\%})\end{array}$ \\
\hline 5 & 4 & $0.119 \pm 0.009$ & $0.332 \pm 0.005$ & 64 \\
5 & 37 & $0.135 \pm 0.016$ & $0.341 \pm 0.004$ & 60 \\
24 & 4 & $0.104 \pm 0.003$ & $0.453 \pm 0.034$ & 77 \\
24 & 37 & $0.090 \pm 0.023$ & $0.398 \pm 0.028$ & 100 \\
\hline
\end{tabular}

${ }^{a}$ Each value represents the mean of three replicate values \pm standard errors. compared with 2 of IgG) leads to a large effect on the dissociation rate, resulting in high binding avidity (King 1998). The IgM antibody used in this study (EMA 212 hybridoma cell line) provided clear test line development in the CLFD format within 6 min. By eye, a detection threshold of approximately $50 \mathrm{~A}$. brassicae conidia was achieved. Assessment using a portable reader (optical densitometry) improved test sensitivity.

Initial reactivity screening of the hybridoma cell lines to other spore types was carried out by PTA-ELISA prior to LF development. The ELISA format lends itself to high-throughput screening of multiple antigens and antibodies and provides a quick primary screen. Because the fungal structure is complex, variation in antigen concentration and type is likely to occur between species. Plant pathology articles often report fungal plate washings and adjustment by dilution

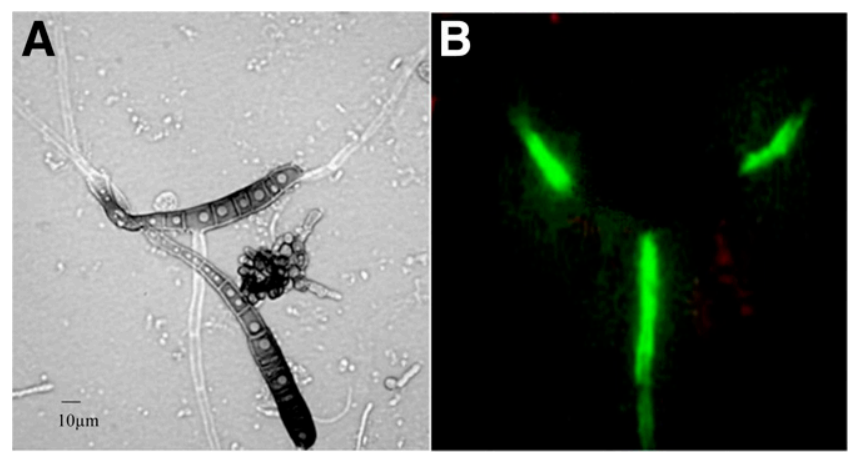

Fig. 2. Visualization of Alternaria brassicae on a glass microscope slide with monoclonal antiserum (hybridoma cell line coded EMA 212) labeled with a fluorescein conjugate as viewed by $\mathbf{A}$, bright-field microscopy and $\mathbf{B}, \mathrm{UV}$ episcopic fluorescence (filter wavelengths at 450 to $560 \mathrm{~nm}$ ).

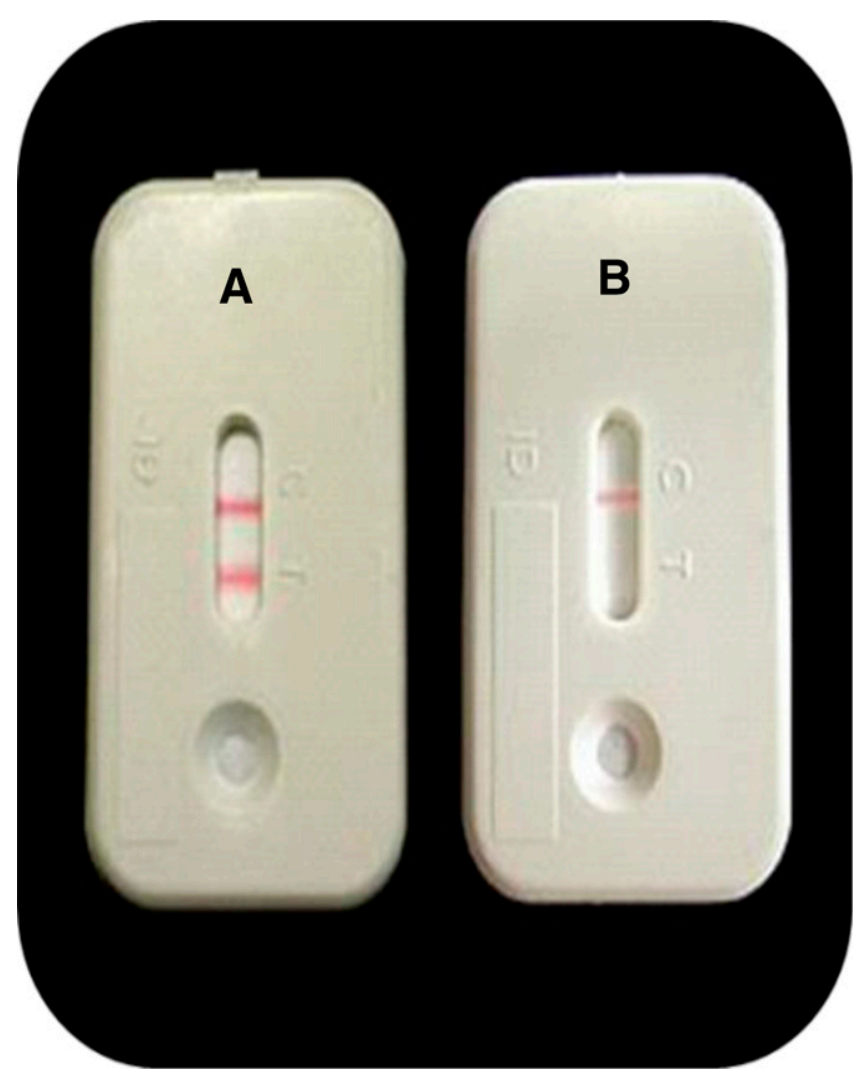

Fig. 3. Visual assessment (by eye) of competitive immunochromatographic lateral flow device assay strips for risk of Alternaria brassicae inoculum in air samples: A, test line development indicates low or no risk and $\mathbf{B}$, no test line development = risk of $A$. brassicae inoculum. 
or weight for immunoreactivity studies rather than protein concentration (Dewey et al. 1990; Bermingham et al. 1995; Kennedy et al. 2000; Meyer et al. 2000). For air sampling, it is standard to relate pollen and fungal spore number by enumeration (British Aerobiology Foundation 1995). Using spore concentration as a normalization factor provides a better measure when relating to the field situation (spores per cubic meter of air sampled). In the development of monoclonal antibodies for the detection of Puccinia striformis urediniospores,

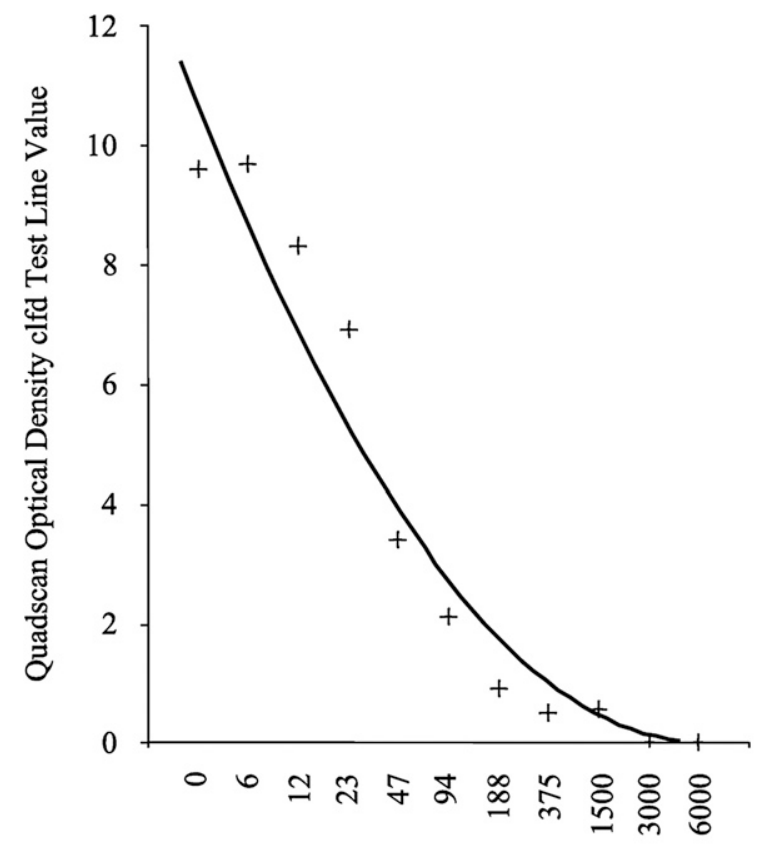

Approximate numbers of $A$. brassicae conidia applied in extraction buffer to a competitive lateral flow device

Fig. 4. Assessment by optical densitometry of competitive immunochromatographic lateral flow device assay strips for measurement of Alternaria brassicae (serial doubling dilution series of $A$. brassicae conidial spore concentration of 6,000 to approximately 6 conidia).

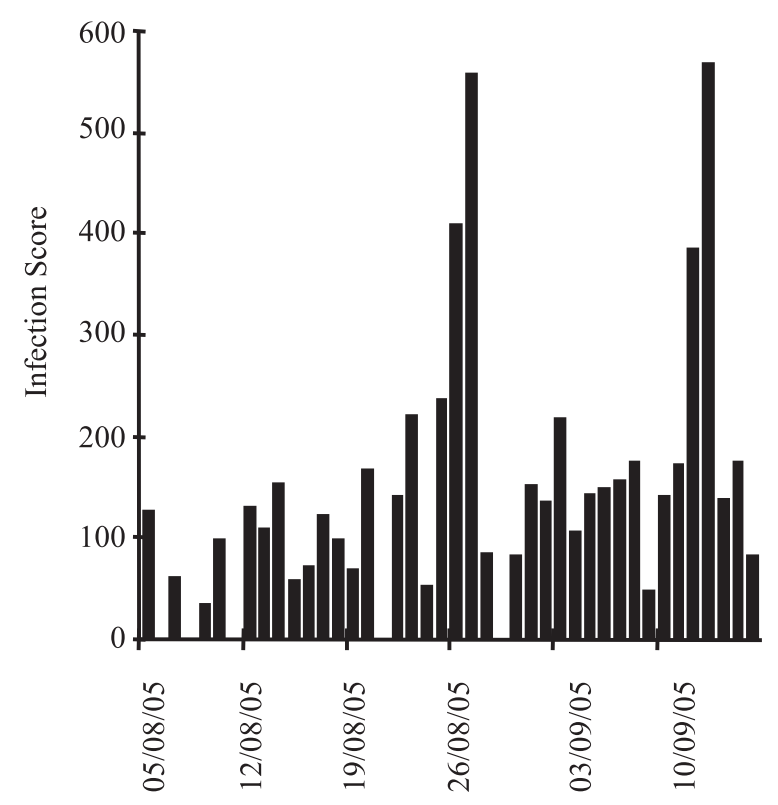

Date

Fig. 5. Daily infection score ratings generated with a weather-based model that identifies infection periods of the dark leaf spot brassica pathogen (Alternaria brassicae), Lincolnshire, UK (Ordnance Survey National Grid reference TF509615).
Skottrup et al. (2007) reported the adjustment of fungal spores for ELISA reactivity testing to $10^{5} \mathrm{ml}^{-1}$ rather than by protein concentration.

Using this methodology, the IgM antibody produced by cell line EMA 212 showed some reactivity to other Alternaria spp. when tested by PTA-ELISA. However, interpreting ELISA data to establish useful thresholds for antibody specificity and sensitivity is arbitrary and dependent on the test requirement. Frequently, positive thresholds used are multiples from two to four of the control mean (Sutula

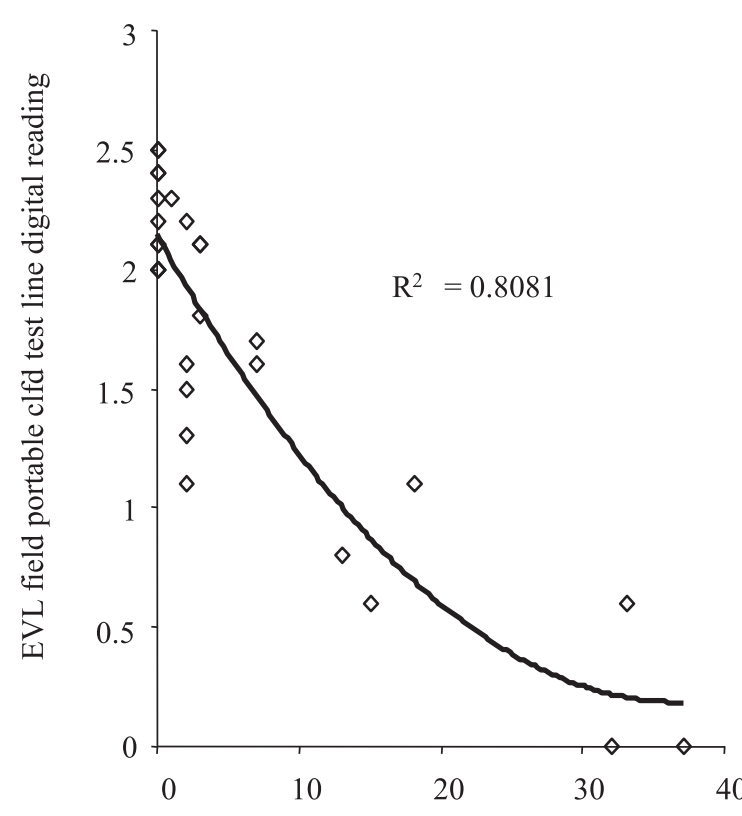

Number of Alternaria brassicae conidia $\mathrm{m}^{3}$ air sampled in a Brussels sprout crop

Fig. 6. Relationship between the number of daily Alternaria brassicae conidia sampled by a multivial cyclone sampler and the corresponding value generated by immunochromatographic strip-type assay for presence of $A$. brassicae conidia.

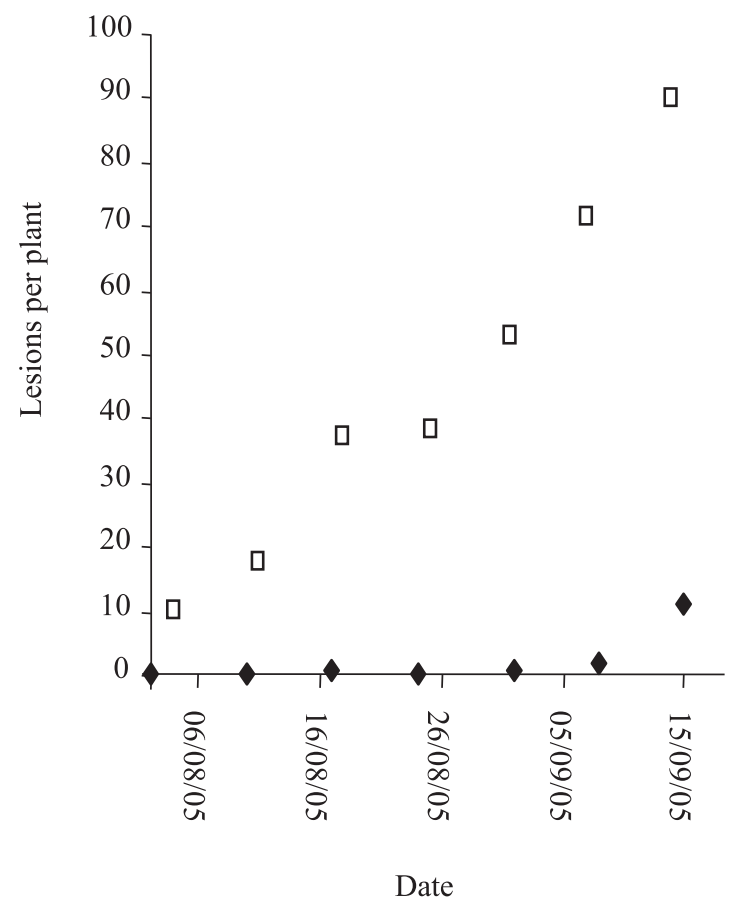

Fig. 7. Dark leaf spot disease development in two U.K. brassica commercial crops: Brussels sprouts ( $\square$ ) Lincolnshire (Ordnance Survey National Grid [OS] reference TF509615) and cauliflower ( $\$$ ) Lancashire (OS reference SD430235) during 2005. 
et al. 1986), with negative controls replicating the solution containing the antigen (Dewey et al. 1997). Using these parameters, the PTAELISA test provided a good measure of discrimination between A. brassicae and the other Alternaria spp. tested, with a 10-fold difference by PTA-ELISA. No significant reactivity was observed for the species tested outside of the Alternaria genus. This was also observed when EMA 212 was incorporated within a CLFD format and additional vegetable brassica pathogen tests included $M$. brassicicola (ringspot) and Pyrenopeziza brassicae (light leaf spot). However, it is important to note the low number of fungal species tested in this study. High-throughput sequencing methods suggest that as many as 5.1 million fungal species exist (Blackwell 2011). A weakness of antibody reactivity testing is the number of isolates that can be accessed and screened easily. Unlike PCR-based technologies, there is no bioinformatics tool available to quickly and remotely screen hybridoma culture supernatants for specificity to target organisms ( $\mathrm{Ye}$ et al. 2012).

In this study, both IgG- and IgM-producing hybridoma cell lines were selected, with reactivity to the two types of $A$. brassicae antigen preparations used. Both isotypes are frequently reported in the development of monoclonal antibodies for fungal diagnostic assays (Skottrup et al. 2007; Werres and Steffens 1994) and found to be equally cross-reactive to the fungal species tested (Dewey et al. 1989). The structurally complex nature of fungi, often with shared immunodominant antigens, makes the development of speciesspecific antibodies difficult (Drouhet 1986; Notermans and Soentoro 1986; Priestley and Dewey 1993). No value of improved specificity or sensitivity could be drawn from the use of different $A$. brassicae conidial antigens (spores produced in culture or in planta) for monoclonal antibody production.

Nevertheless, in combination with prediction of infection, the A. brassicae CLFD assay demonstrated potential for in-field risk assessment to identify periods when brassica crops were at risk from A. brassicae infection. However, for widespread commercial application, the test may require refinement to reflect potential reactivity of the diagnostic probe with other spore types. The development of disruptive technologies over recent years provides application of DNA aptamers, molecular beacons, and quantum-dot LF assays which, if improved specificity is required, could prove useful (Bruno 2014; Sajid et al. 2015; Wang et al. 2014).

Developing accurate risk assessments for plant (and animal) diseases is an important area within epidemiological research. Improving risk assessments for plant diseases in agricultural cropping systems has been useful in the reduction of pesticide applications in the environment (Bugiani et al. 1995; Fry and Fohner 1985; Kennedy and Graham 1995; Wakeham and Kennedy 2010). However, the use of direct detection and quantification of pathogenic inoculum in risk assessments for plant diseases in agricultural production and biosecurity is not routine. One reason for the low usage of direct detection systems has been the cost and speed at which results can be processed and obtained by end users. Detection systems often rely on laboratory facilities in conjunction with specialist knowledge. For these reasons, infection risk (based on environmental conditions) is often used as a risk criteria for controlling plant pathogens in agricultural production systems (Gilles et al. 2004; Magarey et al. 2005). However, although infection is an important part of the plant pathogens life cycle, it does not adequately estimate the real risk of the development of crop diseases. For example, in the present study, infection of $A$. brassicae based on temperature and wetness duration (two major criteria) gave an infection risk on most days within a susceptible crop. Incorporating information on inoculum availability (CLFD test) reduced the number of days when the crop was identified as at risk of infection. The study demonstrates the potential to forecast disease risk in the field at a relatively low cost.

Development of the disease in the field will depend on a number of factors. The plant growth stage at which infection occurs, cultivar, environmental conditions, and inoculum concentration are limiting factors for A. brassicae disease development on oilseed rape (Hong and Fitt 1995). In this study, A. brassicae conidial concentrations were identified as being above a disease risk threshold on three occasions in a Brussels sprout crop using on-site CLFD assays. After the first risk period had been identified, an increase in dark leaf spot symptoms occurred between 14 and 21 days later in the crop. Thereafter, increasing lesion development was observed in the crop. In a cauliflower crop, the disease was first observed on plants 10 days after a CLFD assay predicted a risk of $A$. brassicae. Under optimal conditions in a controlled glasshouse, very small lesions on cauliflower were first observed 6 days after inoculation (Duhan and Suhag 1990).

Risk assessments which include direct measurement of numbers of plant-pathogenic spores in the air should prove useful in predicting the occurrence of pathogens in crops. This is particularly important in systems where pathogen infection causes cosmetic damage and downgrades value by its occurrence (for example, on Brussels sprout buttons). In vegetable crops, the use of $\mathrm{F}_{1}$ hybrids means that pathogen occurrence is usually uniform within the production area. The occurrence of pathogenic inoculum results from interactions with other crops in the area produced under a different production schedule. For example, oilseed rape, which A. brassicae infects, is often unsprayed and grown in proximity to vegetable brassica production. Freshly transplanted summer vegetable brassica crops are often produced adjacent to overwintered and unsprayed vegetable brassica crops. Detecting inoculum will be useful because many of the approved fungicides which control $A$. brassicae infection have systemic activity, allowing good control even when applied after infection has occurred.

It has been reported that one or two peaks in sporangial concentration in the air of the potato blight pathogen Phytophthora infestans preceded the first observed symptoms of the disease in the field (Bugiani et al. 1998). Similarly, the occurrence of detected inoculum was shown before increased disease in the field in the two cropping systems reported on in this study. Recently, it has been shown that spore sampling network devices may provide a suitable approach for early detection of incoming inoculum (Skelsey et al. 2009). When combined with decision support systems, this approach represents a potential aid for targeting the optimal timing of disease control products against $P$. infestans (Fall et al. 2015). In horticultural crops, there is considerable interaction between transplanting date and spatial location. Humpherson-Jones and Maude (1982) reported wind transport of A. brassicae conidia of up to $1.8 \mathrm{~km}$. The epidemiology of $A$. brassicae on local horticultural brassica crops may relate to harvesting of B. napus (Skjøth et al. 2012). Directly measuring airborne inoculum could improve the estimation of risk resulting from the interaction of arable and horticultural brassica crops. However, the number of air samplers and siting of these within a locality requires further research (West and Kimber 2015).

Immunochromatographic tests provide a suitable test format to detect and quantify inoculum in situ (Kennedy and Wakeham 2008; Thornton et al. 2004). The presence of relatively high spore concentrations as a prerequisite for infection means that, in many cases, detecting very low numbers of spores may not be necessary. Studies for the ascosporic fungi Pyrenopeziza brassicae and M. brassicicola (Brassica light and dark leaf spot) have demonstrated that spore inoculum occurs at high concentrations in the air before crop-to-crop transport is possible (Gilles et al. 2004; Wakeham and Kennedy 2010). Therefore, nonmolecular methods are adequate and can provide a low-cost approach when compared with the use of molecular methods (Shan 2011). It should be noted that considerable advances have been made toward the deployment of DNA-based systems to the field and in reducing analysis cost (Thiessen et al. 2015). However, because immunochromatographic devices do not require a preextraction or a DNA amplification stage, they have considerable advantages in both cost and simplicity of use. Also, the crosscontamination of spores from collected field air samples are not likely to prove problematic, as has been reported with the deployment of molecular methodologies in the field (Reiger 2013).

The improvement of immunochromatographic readers since the study was carried out also provides the potential of smartphones for use in a CLFD reading system (Sangdae et al. 2013). The synergistic use of these two technologies demonstrate the potential to help the agri-food industry to assess and predict disease potential in a costeffective way. 


\section{Acknowledgments}

We thank the Department for Environment, Food and Rural Affairs and the Agriculture and Horticulture Development Board for funding this work at the University of Warwick, Warwick HRI, CV35 9EF, UK; and K. Phelps (University of Warwick, HRI) for providing advice on statistical analyses.

\section{Literature Cited}

Bermingham, S., Dewey, F. M., and Maltby, L. 1995. Development of a monoclonal antibody-based immunoassay for the detection and quantification of Anguillospora longissima colonizing leaf material. Appl. Environ. Microbiol. 61:2606-2613.

Blackwell, M. 2011. The fungi: 1,2,3...5.1 million species? Am. J. Bot. 98:426-438.

Booth, C. 1971. The Genus Fusarium. Commonwealth Mycological Institute, Commonwealth Agriculture Bureau International Publishing, Kew, Surrey, UK.

Bossi, R., and Dewey, F. M. 1992. Development of a monoclonal antibody-based immunodetection assay for Botrytis cinerea. Plant Pathol. 41:472-482.

British Aerobiology Foundation. 1995. Airborne Pollens and Spores: A Guide to Trapping and Counting. The British Aerobiology Federation, Harpenden, UK.

Brown, M. C. 2008. Antibodies: Key to a robust lateral flow immunoassay. Pages 59-74 in: Lateral Flow Immunoassay. R. Wong and H. Tse, eds. Human Press, New York.

Bruno, J. G. 2014. Application of DNA aptamers and quantum dots to lateral flow test strips for detection of foodborne pathogens with improved sensitivity versus colloidal gold. Pathogens 3:341-355.

Bugiani, R., Govoni, P., Bottazzi, R., Giannico, P., Montini, B., and Pozza, M. 1995. Monitoring airborne concentration of sporangia of Phytophthora infestans in relation to tomato late blight in Emilia Romagna, Italy. Aerobiologia 11:41-46.

Bugiani, R., Govoni, P., and Cobelli, L. 1998. First large scale application of IPI model for potato late blight prediction in the Po valley. Pages 188-199 in: Proc. Workshop Eur. Network Dev. Integr. Control Strategies Potato Late Blight, Vol. 3 PAV-Spec. Rep. H. Schepers and E. Bouma, eds. Applied Research for Arable Farming and Field Production of Vegetables, Lelystad, The Netherlands.

Carisse, O., McCartney, H. A., Gagnon, J. A., and Brodeur, L. 2005. Quantification of air-borne inoculum as an aid in the management of leaf blight of onion caused by Botrytis squamosa. Plant Dis. 89:726-733.

Calderon, C., Ward, E., Freeman, J., and McCartney, A. 2002. Detection of airborne fungal spores sampled by rotating-arm and Hirst-type spore traps using polymerase chain reaction assays. J. Aerosol Sci. 33:283-296.

Danks, C., and Barker, I. 2000. On-site detection of plant pathogens using lateral flow devices. Bull. OEPP/EPPO Bull. 30:421-426.

Dewey, F. M., MacDonald, M. M., and Phillips, S. I. 1989. Development of monoclonal-antibody-ELISA,-DOT-BLOT and -DIP-STICK immunoassays for Humicola languinosa in rice. J. Gen. Microbiol. 135:361-374.

Dewey, F. M., MacDonald, M. M., Phillips, S. I., and Priestley, R. A. 1990. Development of monoclonal-antibody-ELISA and -DIP-STICK immunoassays for Penicillium islandicum in rice grains. Microbiology 136:753-760.

Dewey, F. M., Thornton, C. R., and Gilligan, C. A. 1997. Use of monoclonal antibodies to detect, quantify and visualise fungi in soils. Adv. Bot. Res. 24: 275-308.

Drouhet, E. 1986. Overview of fungal antigens. Pages 3-38 in: Fungal Antigens, Isolation, Purification and Detection. E. Drouhet, G. T. Cole, L de Repentigny, J.-P. Latge, and B. Dupont, eds. Plenum Press, New York and London.

Duhan, J. C., and Suhag, K. S. 1990. Alternaria leaf and pod blight of cauliflower. Indian Phytopathol. 43:231-234.

Ellis, M. B. 1971. Dematiaceious hyphomycetes. Commonwealth Mycological Institute, Commonwealth Agriculture Bureau International Publishing, Kew, UK.

Fall, M. L., Van der Heyden, H., Brodeur, L., Leclerc, Y., Moreau, G., and Carisse, O. 2015. Spatiotemporal variation in airborne sporangia of Phytophthora infestans: Characterisation and initiatives towards improving potato late blight risk estimation. Plant Pathol. 64:178-190.

Foster, S. J., Ashby, A. M., and Fitt, B. D. L. 2002. Improved PCR-based assays for pre-symptomatic diagnosis of light leaf spot and determination of mating Type of Pyrenopeziza brassicae on winter oilseed rape. Eur. J. Plant Pathol. 108:379-383.

Fry, W. E., and Fohner, G. R. 1985. Construction of predictive models: Forecasting disease development. Pages 161-178 in: Advances in Plant Pathology. Mathematical Modelling of Crop Disease, Vol. 3. C. A. Gilligan, ed. Academic Press Inc., Elsevier, Cambridge, MA.

Gilles, T., Ashby, A., Fitt, B., and Cole, T. 2001. Development of Pyrenopeziza brassicae apothecia on agar and oilseed rape debris. Mycol. Res. 105:705-714.

Gilles, T., Clarkson, J. P., Phelps, K., and Kennedy, R. 2004. Development of MILIONCAST, an improved model for predicting downy mildew sporulation on onions. Plant Dis. 88:695-702.

Hong, C. X., and Fitt, B. D. L. 1995. Effects of inoculum concentration, leaf age and wetness period on the development of dark leaf and pod spot (Alternaria brassicae) on oilseed rape (Brassica napus). Ann. Appl. Biol. 127:283-295.

Humpherson-Jones, F. M. 1992. Epidemiology and control of dark leaf spot of brassicas. Pages 267-288 in: Alternaria: Biology, Plant Diseases and Metabolites. J. Chelkowski and A. Visconti, eds. Elsevier, Amsterdam.

Humpherson-Jones, F. M., and Maude, R. B. 1982. Studies on the epidemiology of Alternaria brassicicola in Brassica oleracea seed production crops. Ann. Appl. Biol. 100:61-71.
Jamaux, I., and Spire, D. 1994. Development of a polyclonal antibody-based immunoassay for the early detection of Sclerotinia sclerotiorum in rapeseed petals. Plant Pathol. 43:847-862.

Johnston, A., and Booth, C., eds. 1983. Mycological media and methods. Page 398 in: Plant Pathologist's Pocket Book, 2nd ed. Commonwealth Agriculture Bureaux, Farnham Royal Slough, UK.

Jones, A. M., and Harrison, R. M. 2004. The effects of meteorological factors on atmospheric bioaerosol concentrations-A review. Sci. Total Environ. 326:151-180.

Kemeny, D. M., ed. 1991. Page 22 in: A Practical Guide to ELISA. Pergamon Press, Amsterdam.

Kennedy, R., and Graham, A. 1995. Forecasting Alternaria brassicae and Mycosphaerella brassicicola in vegetable brassicas. Page 66 in: 10th Bienn. Conf. APPS. Lincoln University, Christchurch, NZ.

Kennedy, R., Phelps, K., and Turner, A. J. 1999a. Prediction of sporulation by Alternaria brassicae and A. brassicicola on Brassica napus. In: 10th Int. Rapeseed Congress, Canberra, Australia. The Regional Institute Online Publishing.

Kennedy, R., and Wakeham, A. J. 2008. Development of detection systems for the sporangia of Peronospora destructor. Eur. J. Plant Pathol. 122:147-155.

Kennedy, R., and Wakeham, A. J. 2015. Measuring biological particles in the air using the Hirst type spore trap: Aerobiology in the age of genomics. Ann. Appl Biol. 166:1-3.

Kennedy, R., Wakeham, A. J., Byrne, K. G., Meyer, U. M., and Dewey, F. M. 2000. A new method to monitor airborne inoculum of the fungal plant pathogens Mycosphaerella brassicicola and Botrytis cinerea. Appl. Environ. Microbiol. 66:2996-3003.

Kennedy, R., Wakeham, A. J., and Cullington, J. E. 1999b. Production and immunodetection of ascospores of Mycosphaerella brassicicola: The ringspot pathogen of vegetable crucifers. Plant Pathol. 48:297-307.

Kennett, R. H., Denis, K. A., Tung, A. S., and Klinman, N. R. 1978. Hybrid plasmacytoma production: Fusion with adult spleen cell, monoclonal spleen fragments, neonatal spleen cells and human spleen cells. Curr. Top. Microbiol. 81:77-91.

King, D. J., ed. 1998. Applications and Engineering of Monoclonal Antibodies. Taylor and Francis Ltd., London.

Köhler, G., and Milstein, C. 1975. Continuous cultures of fused cells secreting antibody of predefined specificity. Nature 256:495-497.

Köhler, G., and Milstein, C. 1976. Derivation of specific antibody-producing tissue culture and tumor lines by cell fusion. Eur. J. Immunol. 6:511-519.

Lawrie, J., Greaves, M. P., Down, V. M., Western, N. M., and Jaques, S. J. 2002. Investigation of spray application of microbial herbicides using Alternaria alternata on Amaranthus retroflexus. Biocontrol Sci. Technol. 12:469-479.

Magarey, R. D., Sutton, T., and Thayer, C. L. 2005. A simple generic infection model for foliar fungal plant pathogens. Phytopathology 95:92-100.

Makela, R., Uusi-Oukari, M., Homanics, G. E., Quinlan, J. J., Firestone, L. L., and Wisden, W. 1997. Cerebellar $\gamma$-aminobutyric acid type A receptors: Pharmacological subtypes revealed by mutant mouse lines. Mol. Pharmacol. 52:380-388.

Malmborg, A. C., Michaelsson, A., Ohlin, M., Jansson, B., and Borrebaeck, C. A. 1992. Real time analysis of antibody-antigen reaction kinetics. Scand. J. Immunol. 35:643-650.

Maude, R. B., and Humpherson-Jones, F. M. 1980. Studies on the seed-borne phases of dark leaf spot (Alternaria brassicicola) and grey leaf spot (Alternaria brassicae) of brassicas. Ann. Appl. Biol. 95:311-319.

McCartney, H. A., and Fitt, B. D. L. 1998. Dispersal of foliar fungal plant pathogens: Mechanisms, gradients and spatial patterns. Pages 138-160 in: The Epidemiology of Plant Diseases. D. G. Jones, ed. Kluwer Publishers.

Meyer, U. M., Spotts, R. A., and Dewey, F. M. 2000. Detection and quantification of Botrytis cinerea by ELISA in pear stems during cold storage. Plant Dis. 84: 1099-1103.

Miller, S. M., Petersen, F. P., Miller, S. A., Rittenburg, J. H., Wood, S. C., and Grothaus, G. D. 1989. Development of modern diagnostic tests and benefits to the farmer. Pages 15-20 in: Monoclonal Antibodies in Agriculture. Laboratory for Monoclonal Antibodies. A. Schots, ed. Pudoc, Wageningen, The Netherlands.

Minchinton, E. J., Auer, D. P. F., Thomson, F. M., Trapnelli, L. N., Petkowski, J. E., Galea, V., Faggian, R., Kita, N., Murdoch, C., and Kennedy, R. 2013. Evaluation of the efficacy and economics of irrigation management, plant resistance and Brassica spot models for management of white blister on brassica crops. Australas. Plant Pathol. 42:169-178.

Nelson, P. E., Toussoun, T. A., and Marasas, W. F. O. 1983. Fusarium species: An Illustrated Manual for Identification. Pennsylvania State University Press, State College.

Notermans, S., and Soentoro, P. S. 1986. Immunological relationship of extracellular polysaccharide antigens produced by different mould species. J. Microbiol. 52: 393-401.

O'Farrell, B. 2013. Lateral flow immunoassay systems Evolution from the current state of the art to the next generation of highly sensitive, quantitative rapid assays. Pages 89-107 in: The Immunoassay Handbook: Theory and Applications of Ligand Binding, ELISA and Related Techniques, 4th ed. D. Wild, R. John, C. Sheehan, S. Binder, and J. He, eds. Elsevier, Amsterdam.

Parada, R. Y., Sakuno, E., Mori, N., Oka, K., Egusa, M., Kodama, M., and Otani, H. 2008. Alternaria brassicae produces a host-specific protein toxin from germinating spores on host leaves. Phytopathology 98:458-463. 
Pitt, J. I., ed. 1988. A Laboratory Guide to Common Penicillium Species. Commonwealth Scientific and Industrial Research Organization Division of Food Processing, Clayton, Australia.

Priestley, R. A., and Dewey, F. M. 1993. Development of a monoclonal antibody immunoassay for the eyespot pathogen Pseudocercosporella herpotrichoides. Plant Pathol. 42:403-412.

Punithalingam, E., and Holliday, P. 1972. Phoma lingam. CMI Descriptions of Pathogenic Fungi and Bacteria. No. 331. Commonwealth Agriculture Bureau International Publishing, UK.

Punithalingam, E., and Holliday, P. 1975. Aschocyta fabae. CMI Descriptions of Pathogenic Fungi and Bacteria. No. 461. Commonwealth Agriculture Bureau International Publishing, Wallingford, UK.

Qian, S., and Bau, H. H. 2004. Analysis of lateral flow bio-detectors: Competitive format. Anal. Biochem. 326:211-224.

Reiger, T. 2013. Spore traps help detect powdery mildew. Vineyard Winery Manage. May-June:64-68.

Rogers, S. L., Atkins, S. D., and West, J. S. 2009. Detection and quantification of airborne inoculum of Sclerotinia sclerotiorum using quantitative PCR. Plant Pathol. 58:324-331.

Sajid, M., Kawde, A. N., and Daud, M. 2015. Designs, formats and applications of lateral flow assay: A literature review. J. Saude Chem. Soc. 19:689-705.

Sangdae, L., Giyoung, K., and Moon, J. 2013. Performance improvement of the one-dot lateral flow immunoassay for Aflatoxin B1 by using a smartphonebased reading system. Sensors 13:5109-5116.

Schmechel, A. C., McCartney, H. A., and Magan, N. 1996. A novel approach for immunomonitoring airborne fungal pathogen. Pages 93-98 in: Diagnostics in Crop Production. British Crop Prot. Counc. Symp. Proc. Univ. Warwick, UK. G. Marshall, ed. Farnham Press, London.

Shan, G., ed. 2011. Implications of testing for trade. Pages 311-320 in: Immunoassays in Agriculture Biotechnology. Wiley Press, Hoboken, NJ.

Skelsey, P., Kessel, G. J. T., Holtslag, A. A. M., Moene, A. F., and van der Werf, W. 2009. Regional spore dispersal as a factor in disease risk warnings for potato late blight: A proof of concept. Agric. For. Meteorol. 149:419-430.

Skjøth, C. A., Sommer, J., Frederiksen, L., and Gosewinkel, K. U. 2012. Crop harvest in Denmark and Central Europe contributes to the local load of airborne Alternaria spore concentrations in Copenhagen. Atmos. Chem. Phys. 12:11107-11123.

Skottrup, P., Frokiaer, H., Hearty, S., O'Kennedy, R., Hejgaard, J., Nicolaisen, M., and Jusesen, A. F. 2007. Monoclonal antibodies for the detection of Puccinia striformis urediniospores. Mycol. Res. 111:332-338.
Sutula, C. L., Gillett, J. M., Morrissey, S. M., and Ramsdell, D. C. 1986 Interpreting ELISA data and establishing the positive-negative threshold. Plant Dis. 70:722-726.

Thiessen, L. D., Keune, J. A., Neill, T. M., Turechek, W. W., Grove, G. G., and Mahaffee, W. F. 2015. Development of a grower-conducted inoculum detection assay for management of grape powdery mildew. Plant Pathol. 65: 238-249.

Thornton, C., Groenhof, R. F., and Lamotte, R. 2004. A one-step immunochromatographic lateral flow device specific to Rhizoctonia solani and certain related species and its use to detect and quantify $R$. solani in soil. Phytopathology 94:280-288.

Wakeham, A. J., and Kennedy, R. 2010. Risk assessment methods for the ringspot pathogen Mycosphaerella brassicicola in vegetable brassica crops. Plant Dis. 94:851-859.

Wakeham, A. J., Kennedy, R., and McCartney, H. A. 2004. Using ELISA to monitor the collection and retention of a range of common airborne spore types in air-samples. J. Aerosol Sci. 35:835-850.

Wakeham, A. J., Pettitt, T. R., and White, J. G. 1997. A novel method for detection of viable zoospores of Pythium in irrigation water. Ann. Appl. Biol. 131: 427-435.

Wang, H., Li, Y., Wank, A., and Slavik, M. 2014. Rapid, sensitive, and simultaneous detection of three foodborne pathogens using magnetic nanobead-based immunoseparation and quantum dot-based multiplex immunoassay. J. Food Prot. 12:2000-2228, 2039-2047(9).

Werres, S., and Steffens, C. 1994. Immunological techniques used with fungal plant-pathogens-Aspects of antigens, antibodies and assays for diagnosis. Ann. Appl. Biol. 145:1-16.

West, J. S., Atkins, S. D., Emberlin, J., and Fitt, B. D. L. 2008. PCR to predict risk of airborne disease. Trends Microbiol. 16:380-387.

West, J. S., and Kimber, R. B. E. 2015. Innovations in air sampling to detect plant pathogens. Ann. Appl. Biol. 166:4-17.

Wong, R., and Tse, H., eds. 2009. Lateral Flow Immunoassay. Humana Press, Springer, New York

Yager, P., Gonzalo, J. D., and Gerdes, J. 2008. Point-of-care diagnostics for global health. Annu. Rev. Biomed. Eng. 10:107-144.

Ye, J., Coulouris, G., Zaretskaya, I., Cutcutache, I., Rozen, S., and Madden, T. L. 2012. Primer-BLAST: A tool to design target-specific primers for polymerase chain reaction. BMC Bioinf. 13:134-144.

Zink, K., Vogel, H., Vogel, B., Magyar, D., and Kottmeier, C. 2012. Modelling the dispersion of Ambrosia artemisiifolia L. pollen with the model system COSMO-ART. Int. J. Biometeorol. 56:669-680. 